\title{
A self-access learning facility in a Libyan University
}

\section{Ms. Msimeer Amel \\ Misurata University}

\section{Introduction:}

"The introduction of Self -Access Language Learning (SALL) requires change in the roles of learners, teachers and institutions." (Gardner and Miller, 1999, p.13). SALL is a concept which has developed as a result of the promotion of autonomous learning which takes place without the teacher's control. Nevertheless, establishing SALL in any educational institution will require the institution to be aware of the abilities and constraints that it has. Furthermore, getting the teachers and the students involved in this will necessitate change to their traditional roles. In this article I will focus on SALL and how its application can change the roles of the institution, teachers and students. The article has two phases: theoretical and practical. The theoretical phase deals with the definition of SALL, the relationship between the SALL and the belief of autonomy, the existence of the self access centre (SAC) and the change of roles while the practical phase presents a simple design of a SAC in a Libyan university .

\section{Definitions of SALL:}

The term Self Access Language Learning (SALL), in the literature of English Language Teaching, appears to be defined in relation to the development of learner autonomy. Riley (1986), for example, defines it as the concept of promoting language learners to identify their learning 
needs and objectives. Furthermore, Sheerin (1991, p.143) describes SALL as " a way of describing learning materials that are designed and organised in such a way that students can select and work on their own and obtain feedback on their performance". Gardner and Miller (1999) see self access as an integration of all these elements mentioned in the above two definitions. They also refer to it as an approach to learning rather than teaching.

\section{Learner Autonomy and SALL:}

Learner autonomy has increasingly been a goal in education. It describes a situation where learners have the ability to take charge and make decisions about their learning independently (Scharle and Szabo, 2000). Both being independent and autonomous can be potentially related to SALL in a number of ways.

Firstly, learner autonomy is linked to the notion of individualisation. To illustrate, learners vary in their interests, and learning needs. Also, learners have different learning styles and cognitive abilities. Thus SALL accommodates all of the above by providing a set of facilities which allow the learners to satisfy their individual learning interests, goals and needs which they can work on either alone or with others (Benson and Voller, 1997). Another way in which SALL can facilitate autonomy is through materials which raise the learners' awareness about their learning process by highlighting some aspects of managing learning, such as setting goals and monitoring progress (Cotterall et al., 2001). Finally computer-assisted language learning, which the SALL adapts, can promote learners' autonomy by providing a 
variety of learning materials to cater for their individual needs (Benson, 2001 and Benson and Voller1997).

\section{The Language Classroom and the SAC:}

Traditional language classrooms seem to be environments where learners are passive recipients of information in that they have little opportunity to discuss their views with their teachers or to participate in the learning process. Rather, teachers play a dominant role as they are the main providers of materials, tasks and activities conducted in the class (Hedge, 2000). However, these activities and materials, in many cases, do not necessarily address the individual learner's needs and interests. In addition, the class time might not offer the learners equal opportunity to practise their language.

McMurry et al. (2009) state that the primary role of a SAC is to facilitate autonomous learning. Furthermore, Sheerin (1997) demonstrates that catering for individualisation is one of the reasons for the emergence of the SAC. Accordingly, establishing SACs in schools and universities, which aim to promote learner autonomy, would be effective. The centre will provide learners with a wide variety of pedagogical learning materials which will complement the learning taking place in the classroom (McMurry, 2009). Furthermore, these materials will accommodate learners of different levels, styles, goals and interests (Crottell, 2001).

\section{Resources and Systems in the SAC:}

As has been mentioned above, the learning materials, which the SAC contains, is a key issue in the success of the centre. According to Dickinson (1987) self access is a collection of learning materials which are designed and organised in a particular way making them directly 
available to the learners. Based on this, the learning materials which are available need to cater for the different needs of the learners. Furthermore, they should be regularly updated to offer the learners chance to keep up with the latest innovations in the field of language learning and to keep them motivated. Regarding the organisation and the displaying system of the materials; systems, such as menu-driven, supermarket, controlled access and open-access and others are designed to make finding the materials easy (Miller and Rogerson-Revell, 1993). Another way to organise materials in the SAC is to classify them into categories through a colour-coded system; each colour identifying a particular type of material and level (Decker, 2004). Another helpful idea, related to the learning materials, is having assessment sheets which provide the learners with feedback on their performance. This feedback not only provides possible answers, but also rubrics which show the learners how much they have progressed.

\section{The Role of the Institution:}

Setting up a SAC in an educational institution is not an easy task. It requires the institution to make decisions about a number of issues, such as purchasing the learning facilities, and the attitude of people (Sturtridge, 1992, Gardner and Miller, 1999).

Benson, (2001) states that the first key issue for the implementation of SALL is the accessibility of substantial funds. Salvia (1999) alleges that the SAC should not only rely on the initial capital allocated for the purchasing and development of resources, such as books, software and computers but also on funding assigned for staff salaries, repair services, updating of materials and other ongoing costs. Gardner 
and Miller (1999) support this as they classify the budget of self access into two categories: starting-up and recurrent. While the former is intended to establish the SAC, the latter is assigned for salaries, and improvements.

Another issue is people's attitudes towards setting up a SAC. Jones (2004, p.25) states, "...the majority of SACs cannot do without high technology. Students expect to find computers among the facilities available for them". However, Sheerin, (1991) argues that there are many successful SACs in the world which are based on simple means for example, radios and homemade materials.

\section{The Teacher's Role:}

When establishing SALL, the teacher's role changes considerably. Therefore, they relinquish their control and allow for more flexibility in the learning process. The new roles, which the teacher adopts, are, for example, facilitator, counsellor, advisor and helper (Riley, 1997; Riley, 1986) besides other roles such as organiser, administrator, assessor which he is already familiar with (Gardner and Miller, 1999).

Being a counsellor, the teacher, helps the students develop their learning competence by providing them with information on both metcognitive and metalinguistic strategies. He also enables them to make a choice of appropriate materials and work techniques. Kelly (1996) demonstrates that the process of counselling takes the form of 'therapeutic dialogue' in which one-to-one sessions are held and where a counsellor enables the learners to deal with their problems. Voller et al. and Pemberton et al. (cited in Benson, 2001) argue that counsellors in some 
cases might go beyond the basic function of their role and provide advice which can be direct and cause the learner not to gain adequate benefit .

Other roles, which a teacher can fulfil, in a self access programme, are facilitator and advisor through which the teacher helps the learners identify their learning needs and goals. Nevertheless, Sheerin (1997) points out those ill-prepared teachers who adopt these roles might be too dominant and therefore jeopardize learner autonomy.

Finally, attitudes which teachers hold can influence their learners' exploitation of the SAC. In other words teachers who hold a positive attitude will encourage and motivate their learners to use the materials available in the SAC while those with a negative attitude will not do so (Littlejohn, 1985).

\section{The Learners' Role:}

Learners in traditional language classrooms play a passive role. They are dependent recipients who absorb the learning materials delivered by the teacher during the lesson. However, when SALL is employed, the more traditional roles require modification.

SALL is based on the concept of promoting learners to be independent and take responsibility for identifying their own needs and objectives (Riley, 1986). Furthermore, when engaged in SALL, students choose their own learning materials, use facilities themselves, make decisions about their learning and assess their progress (Sheerin,1989). Getting language learners to conduct all of these tasks could be quite overwhelming for learners whose cultural backgrounds, attitudes and beliefs suggest a more traditional approach to learning (Benson, 2001). 
The employment of SALL in societies which focus on collectivism can cause some challenges to the students as one key feature of SALL is encouraging individual learning (Gremmo and Riley, 1995). However, Farmer's (1994) study revealed that SALL in Hong Kong universities worked well and that in some cases, the students' reliance on their teacher seemed to become gradually less and less. Furthermore, Smith (2003) with regard to this argument states, "learners of whatever background and culture are already able, at least to some degree, to exercise control over their own learning (cited in Smith, 2008).

The learners' attitudes and beliefs can also have an effect upon their level of acceptance of self access. Lee (1998) claims that students with high enthusiasm enjoy being engaged in self study tasks and they have a desire to continue their independent learning while students who are heavily dependent on the teacher will be less enthusiastic to continue with this type of learning.

\section{Preparation and Training for SALL:}

The change in the roles might not work properly unless some training is offered. Trim (cited in Sheerin, 1991) demonstrates that when implementing SALL, learners need, initially, to be introduced to the idea of self access by means of conferences and short talks (Riely, 1997). Furthermore, as part of their training, they need to be helped to identify their needs and set their own objectives by one-to-one or group sessions (Riley, 1986).

To make this work, the teacher needs to be trained. They need to be familiar with the theories of self access and the new roles which they will adopt. This considerable change has, in turn, an influence upon the 
educational institution in terms of budget, staff and facilities. Thus, it is worthwhile for the mangers of the institution to see other centres where the self access is working effectively and they can be made aware of the financial constraints (Sheerin, 1991).

\section{The Learning Context:}

The context about which I am writing is the Faculty of ArtsMisurata University in Misurata, Libya. The SAC presented here will be particularly for Libyan students who major in English language. These students are freshmen, juniors and seniors and they attend class six times a week; each class lasting two hours. The students will be expected to use the centre after classes or during the break time. The English Language Department employs twenty-three members of staff, some of whom are local and some from other countries, such as India and Philippine. Although these teachers adopt current techniques and strategies in their teaching, traditional teaching is still dominant in some classes. The Libyan government will financially support the department.

\section{Rationale for Establishing a SAC:}

- Encouraging the Libyan students to become autonomous and enabling them to identify their own learning needs and objectives.

- Contributing to the development of close relationships between the Libyan students and their teachers, particularly when teachers adopt new roles such as counsellor, facilitator and advisor.

- Helping the Libyan students have immediate feedback on their performance and enabling them to be aware of any difficulties which they need to improve.

- Compensating for the time limit of the class. 
- Offering a variety of materials, thus avoiding repetition and therefore boredom during the lessons.

- Getting Libyan students to develop the habit of lifelong learning which, in turn, can be useful for their professional life in the future.

- Offering Libyan students the opportunity to study English without the teacher's control.

- Building up the reputation of the English language department in the university so that more students will be attracted to and want to join this department.

- Establishing a SAC in Misurata University would help the Libyan teachers in the department of English to become familiar with the latest innovations in the field of teaching and learning of English language.

- Giving the teacher the chance to pay equal attention to the individual needs of all the students in large classes.

\section{Types of SAC:}

There are different types of self access systems, for example, menu-driven, talking shop and others (Gardener \& Miller, 1999). The type of system to be used in the Libyan context is 'supermarket'. This system displays the learning materials under clear categories, such as speaking, listening and others which are colour-coded according to levels (Miller \& Rogerson-Revell, 1993). This way of organisation will seemingly offer the Libyan students opportunity to easily find and select what to study. 
Furthermore, the supermarket system is preferred in this context because it is less expensive than the menu-driven type.

\section{Staffing and Management:}

- Head of the SAC

One of the teachers in the English language department will be the head of the SAC. He has some experience in managing SACs. In addition, this teacher has a reduced teaching timetable allowing him more time to devote to the centre. He will be responsible for planning the use of the centre, sorting out problems, looking for ways of improving the facilities and making the centre run smoothly.

- Technical Assistance

Technicians and computer experts who work for the university will be available for providing help in the SAC.

- Counsellor

There will be two tutors fulfilling this role. One is a parttime staff member (teacher) while the other is a full-time counsellor whose sole responsibility will be to provide the users of the SAC with help and advice on their language learning.

- Administrative staff

The SAC will have two full- time administrators, whose duties will be to check the use of the learning resources, control noise, locate books and monitor security.

Having a flexible management system in the SAC, facilitating the exchange of information between the staff and managers, results in a 
productive working environment (Gardner\& Miller 1999). Therefore, the management model to use in this SAC is Democratic (ibid, 1999). This is so that both language teachers and students can contribute to the development of learning materials and share ideas between the staff of the centre and the users about how the SAC can be improved.

\section{Physical Settings and Resources:}

The layout and design of the SAC is important. Having a welcoming and non threatening atmosphere encourages both learners and teachers to visit and use the centre. The SAC will be located on the second floor and to help learners find it, sign posts will be used. This centre will be divided into eight sections (see appendix); each of these having its particular function.

The first section is the reception and information desk which is in the entrance area. The students here can borrow and return learning materials and can ask for help from the staff at the desk about how to find materials on the shelves. The next area will be for the journals and magazines which are near the reception desk. Students can read these while waiting for their turn to use the computers.

The third area in the centre will be the computer section which will have twenty five computers. The students can use these to download and to print out learning materials and worksheets. Furthermore, the computers in this section will have software enabling learners to choose learning activities that address their individual needs. The software will also provide the students with feedback on their performance. Next to this is the listening section which will be designated for listening activities. It is equipped with gadgets, such as CD players, TV's and video recorders. 
Libyan students, who like silent reading and quiet areas, can sit in one of the study rooms which are away from the entrance. On the opposite side of the silent study rooms, there will be a big conference room where the students can practise for seminars and presentations. This area will be supplied with an overhead projector and screen. The next area will be the counsellor's desk where the students can get support and advice on their learning.

The last area will be designated for the bookshelves providing a wide variety of printed and audio and visual self study materials dealing with the four language skills. They are classified into categories according to the level of difficulty and are labelled in different colours according to the skill they deal with. To find out about the centre, the students are offered a user's guide booklet containing useful details. As for the opening hours, the centre will be open every day from 9:00 am to 4:00 pm except for the weekend: Friday.

\section{Difficulties in Establishing a SAC:}

- Some Libyan students might not accept the idea of working on their own as they hold the belief that the teacher knows more about what they need and about their progress in learning.

- Some students might visit the SAC and use the computers and the Internet for other purposes, for example checking their emails rather than surfing learning websites. To deal with this, the computer experts and technicians could programme the computers so that students can access particular websites and block others.

- The SAC might not get help from other institutions or organisations in terms of running training courses for the staff. 
- The Libyan students, when speaking in the SAC, might make too much noise which will disturb the other users. Consequently, the reception desk should be located in the central area in the SAC in order to control the level of noise.

- Available learning materials and the number of the computers might not cater to the large number of the students. Therefore, the materials would be put on short loan while the computers will need to be booked at the reception desk in advance.

- The size of the SAC might not cater for the large number of students. Thus it will be better to assign particular hours and days for each level.

In brief, self access facilities appear to be a valuable means of learning as they enable learners to build up confidence and be independent. However, the establishment of such a facility will not be easy. Regarding the idea of the SAC I have presented in this article, there would be some difficulties, such as the necessary changes in roles and learners' beliefs, but with considerable effort, I suggest, it is possible to make it work. 


\section{ppendix: The floor plan of the SAC}

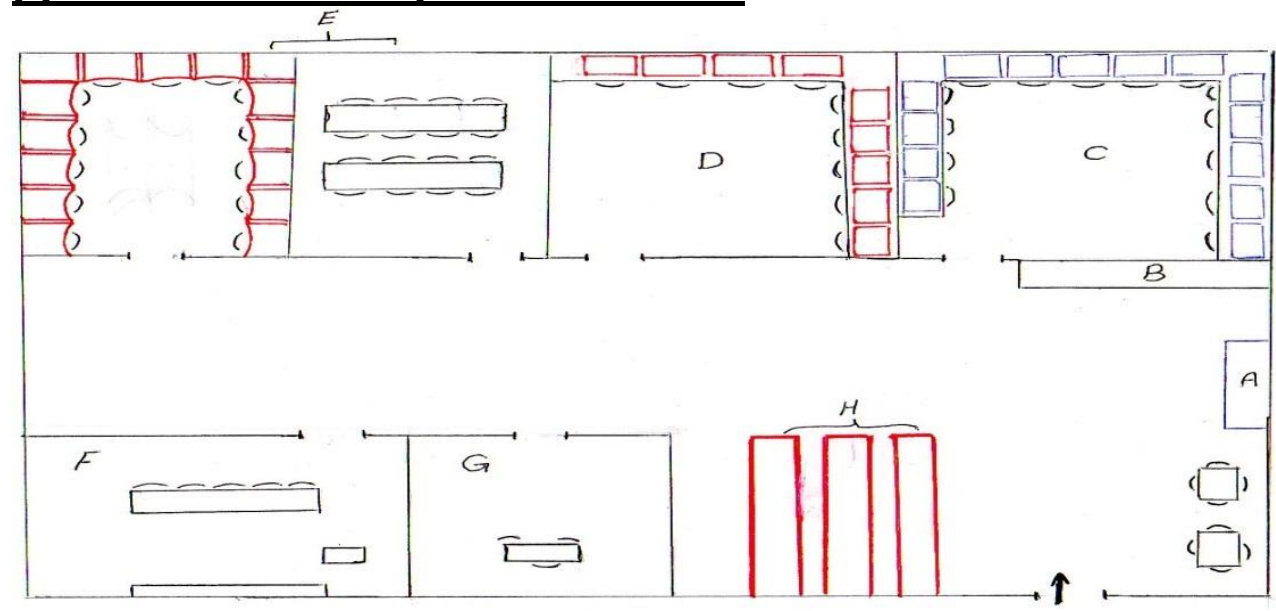

\section{AREAS IN THE SAC:}

A- Reception and information desk.

B- Magazines and journals shelves.

C- Computers section.

D- Listening section.

E- Two study rooms.

F- Conference room.

G- Counsellor desk.

$\mathrm{H}-$ Books and audio and visual materials. 


\section{References}

Benson, P. \& Voller, P. (1997) 'Introduction: autonomy and independence in language learning'. In Benson, P \& Voller, P (eds). Autonomy and independence in language learning. Harlow: Addison Wesley Longman Limited. Pp. 1-12.

Benson, P. (2001) Teaching and researching: autonomy in language learning. Harlow: Pearson Education Limited.

Cotterall, S. \& Reinders, H. (2001) 'Fortress or bridge? Learners' perception and practice in self-access language learning'. Tesolanz. 8, Pp. 23-38.

Decker, M. (2004) 'Incorporating guided self-study listening into the language curriculum'. The language teacher. 28 (6) Pp. 5-9.

Dickenson, L. (1987) Self-instruction in language learning. Cambridge: Cambridge University Press.

Farmer, R. (1994) 'The Limits of learner independence in Hong Kong'. In Gardner, D. \& Miller, L. (eds). Direction in self-access language learning. Hong Kong: Hong Kong University Press. Pp. 13-27.

Gardner, D. \& Miller, L. (1999) Establishing self access: from theory to practice. Cambridge: Cambridge University press.

Gremmo, M. \& Riley, P. (1995) 'Autonomy, self-direction and self-access in language teaching and learning: the history of an idea'. System, 23 (2), 151-164.

Hedge, T. (2000) Teaching and learning in the language classroom. Oxford: Oxford University Press. 
Jones, J. (2004) 'Self-access language learning: more than just technology'. The Language Teacher. 28 (6) pp. 25-26.

Kelly, R. (1996) 'Language counselling for learner autonomy: the skilled helper in self-access language learning'. In Pemberton, et al. (eds) Taking control: autonomy in language learning. Hong Kong: Hong Kong University Press. Pp. 92-113.

Lee, I. (1998) 'Supporting greater autonomy in language learning'. ELT Journal. 52 (4) pp. 282-290.

Littlejohn, A. (1985) 'learner choice in language study'. ELT Journal. 39 (4) Pp. 253-261.

McMurry, B et al. (2009) 'Self -access centers: maximizing learners' access to centre resources'. Tesl, EJ. 12 (4) Pp. 1-13.

Miller, L. \& Rogerson-Revell, P. (1993) 'Self-access systems'. ELT Journal. 47 (3) Pp. 228-233.

Riley, p. (1986) 'Who's who in self-access'. TESOL France News. 6 (2). Pp. 23-35.

Riley, P. (1997) 'The guru and conjurer: aspects of counselling for selfaccess'. In. Benson, P. and Voller, P. (eds) Autonomy and independence in language learning. Harlow: Addison Wesley Longman Limited, Pp. 114-131.

Salvia, O. (2000) 'Integrating a self access system in a language learning institution: a model for implementation'. Links and letters. 7. Pp. 95109.

Scharle, A. \& Szabo, A. (2000) Learner autonomy: a guide to developing learner responsibility. Cambridge: Cambridge University Press.

Sheerin, S. (1989) Self access. Oxford: Oxford University press. 
Sheerin, S. (1991) 'State of the art article: self access'. Language teaching. 24 (3). Pp. 143-157.

Sheerin, S. (1997) 'An exploration of the relationship between self-access and independent learning'. In Benson, P. \& Voller, P. Autonomy and independence in language learning. Harlow: Addison Wesley Longman Limited. Pp. 54-65.

Smith, R. (2008) 'Learner autonomy’. ELT Journal. 62 (4) Pp. 395-397.

Sturtridge, G. (1992) Self-access: preparation and training. Manchester: British Council. 